NBER WORKING PAPER SERIES

\title{
PRODUCTIVITY LEVELS AND PRODUCTIVITY \\ CHANGE UNDER UNIONISM
}

Steven G。Allen

Working Paper No. 2304

\section{NATIONAL BUREAU OF ECONOMIC RESEARCH 1050 Massachusetts Avenue Cambridge, MA 02138 July 1987}

Financial support was provided by the National Science Foundation and North Carolina State University. John Abowd, Richard Freeman, Casey Ichniowski, Tom Kniesner and Sol Polachek provided helpful comments on earlier versions of the paper. Myra Ragland and Katherine Foote were excellent research assistants. The research reported here is part of the NBER's research program in Labor Studies. Any opinions expressed are those of the author and not those of the National Bureau of Economic Research. 
NBER Working Paper \#2304

July 1987

\section{Productivity Levels and Productivity Change Under Unionism}

\section{ABSTRACT}

This paper examines how unions affect the rate of productivity change over time. The direction of union impact cannot be predicted from economic theory. Firms may tend to select more productive technologies to offset the cost of higher union wages or they may tend to select less productive technologies to keep union wage demands in line. Evidence from manufacturing indicates that unions have not affected productivity growth, but in the construction industry productivity growth has been much slower in areas where there is a high initial level of unionization or where unionization is growing.

Steven G. Allen

Department of Economics and Business

Box 8110

North Carolina State University

Raleigh, NC 27695-8110 


\section{I . INTRODUCTION}

Roughly 10 years ago researchers started to produce quantitative estimates of the impact of unionism across cross sections of firms or industries. The results of this research, summarized in Freeman and Medoff (1984), show that in most instances productivity is much higher at a given point in time under unionism .

These studies have not considered the question of how unions affect productivity over time. The use of cross section data sets has largely precluded the examination of this set of issues, with one notable exception. Connerton, Freeman and Medoff (1983) use repeated cross sections and find that productivity in union bituminous coal mines was 33 to 38 percent higher than in nonunion mines in 1965 , but 14 to 20 percent lower in 1975 and 1980 . They attribute the decline of the union coefficient to the deterioration of labor-management relations during that time period, a perfectly legitimate inference given the theoretical framework within which all of these studies (including, of course, my own) has been embedded. The exit-voice model emphasizes turnover, training, and labor-management interaction, but pays scant attention to such dynamic factors as investment in $R \& D$, lags in adopting new techniques, and organizational change.

This paper examines how unions affect the rate of productivity change over time. Considering both price theoretic and institutional factors, the impact of unionism on productivity change cannot be predicted ex ante. Just as in the case of cross section union-nonunion differences in productivity levels, the question of whether unions promote or retard productivity change is an empirical issue. The evidence reported below indicates that unions have had no 
impact on productivity change in manufacturing, whereas in construction productivity growth has been much slower under unionism.

\section{PRODUCTIVITY CHANGE UNDER UNIONISM}

In cross section analyses union-nonunion productivity differences can arise through union effects on turnover, training, work rules, labor-management communication, worker morale, and management behavior. Using a Cobb-Douglas production function $Q_{t}=\left(A_{n}+c U_{t}\right) L_{t} a_{t} b$, the net impact of all of these sources of productivity differences between union and nonunion observations in a cross section can be determined by estimating the parameter c. Suppose now that two cross section data sets are available. Then after taking log differences, the parameter c can also be estimated with the equation

$$
d \log (Q / L)_{t}=c * d U_{t}+b * d \log (K / L)_{t}+(a+b-1) * d \log L_{t}
$$

In this specification, productivity changes are entirely a function of changes in percentage unionized, the capital-labor ratio, and establishment size. If the model has been correctly specified and if there is no measurement error in the data set, one should get the same estimate of c from either the conventional cross section equation or the log difference equation (1).

The parameter $\mathrm{c}$ in (1) is assumed to be constant in each period. This assumption is inappropriate whenever productivity shocks occur within either the union or nonunion sector. For instance, if relations between labor and management deteriorate, as was the case in the bituminous coal industry in the period examined by Connerton, Freeman, and Medoff, one would expect c to 
decline. Also, c could change as a result of changes in the sources of union-nonunion productivity differences. For instance, if changes are made in union work rules to allow management greater flexibility in assigning workers to jobs, this would cause $c$ to rise. If $c$ is allowed to very over time, the product of the change in $c$ and the initial level of percentage unionized must be added to (1):

$$
d \log (Q / L)_{t}=c_{t} * d U_{t}+b * d \log (K / L)_{t}+(a-b-1) * d \log L_{t}+d c * U_{t-1}
$$

The assumption of a constant value of $c$ in (1) is also inappropriate when there is a difference in the rate of technical change between the union and nonunion sectors. Let $\mathrm{d}_{0}=$ annual rate of technical change under unionism and $d_{1}=$ annual rate of technical change in the nonunion sector. Then the production function becomes $Q_{t}=\left(A_{n}+c U_{t}\right) L_{t}{ }^{a} K_{t} b \exp \left\{\left(d_{0} U_{t}+d_{1}\left(1-U_{t}\right)\right) t\right\}$ and the estimating equation is now

$$
\begin{aligned}
\mathrm{d} \log (\mathrm{Q} / \mathrm{L})_{t}=\mathrm{c} * d U_{t} & +b * d \log (\mathrm{K} / \mathrm{L})_{t}+(\mathrm{a}+\mathrm{b}-1) * d \log L_{t} \\
& +\left(\mathrm{d}_{0}-\mathrm{d}_{1}\right) * \mathrm{U}_{\mathrm{t}-1}+\mathrm{d}_{1} \mathrm{t}+\left(\mathrm{d}_{0}-\mathrm{d}_{1}\right) t * d U_{t}
\end{aligned}
$$

As one can see from comparirg (2) and (3), changes in labor-management relations (or other factors which may cause $c$ to vary over time) and unequal rates of technical change between the union and nonunion sectors are econometrically equivalent in terms of their effects on productivity change. In each case both the initial level of unionization and the change in unionization appear on the right hand side of the equation.

Unions are likely to influence productivity change through both price theoretic and institutional mechanisms. Changes in the union-nonunion wage gap lead to factor substitution decisions that will change labor productivity, but 
have no effect on total factor productivity. The change in the capital-1abor ratio controls for this spurious source of productivity change in (3).

Union wage behavior becomes a more critical factor when the technology itself is endogenous. Tauman and Weiss (1984) show that under certain assumptions unionized firms are more likely to choose the most productive technology. They consider the case of a duoploy where one firm is unionized and the other is nonunion. These firms participate in a two-stage non-cooperative game with the union. In the first stage the firms choose their technology while the union simultaneously chooses the wage. Output and employment are determined in the second stage. Both firms initially have the same technology, but each can purchase and install a more productive technology at the same cost. Labor is assumed to be the only factor of production, so the more productive technology must be labor-saving.

The decision to adopt this technology hinges on product demand. At very low demand levels, neither adopts, and at very high demand levels, both adopt. The key difference between the union and the nonunion firm is that the union charges its firm higher wages at high levels of output, while the nonunion firm pays the same, competitive wage at all output levels. Thus the union firm stands to gain more than the nonunion firm from adopting the more productive technology at some output levels and it is possible to have a solution where only the union firm uses that technology.

This result is very sensitive to the assumption that the union selects its wage at the same time that the firms select their technologies. If the union can alter its wage after the technologies have been chosen, it has the ability to appropriate the returns from the increase in productivity. Realizing this, the union firm is less likely than the nonunion firm to adopt the best 
technology and it is impossible to have an equilibrium where only the union firm uses the most productive technology.

Union firms may also want to keep some low productivity capacity in operation as part of a strategy to keep union wage demands in line. Baldwin (1983) shows that when the capital replacement cycle is long relative to the time horizon of the union, in the absence of enforceable long-term wage contracts, it is optimal to invest in both efficient and inefficient capacity rather than to invest only in the former. If firms invest only in the most efficient capacity, they are subject to the risk of higher union wage demands in the future, as pointed out by Tauman and Weiss. However, by investing in both types of capacity, unions will be less likely to make such demands because some of the less efficient capacity would no longer be profitable to operate and employment would fall, lowering the union's utility. Although this strategy results in lower productivity growth in unionized industries, it is optimal from the standpoint of investors because it guarantees them some return on new capital investments.

Both the Tauman and Weiss and the Baldwin models are couched in terms of certain returns to investment in more productive capacity. Nelson (1981) has emphasized that two key aspects in the process of technical change -. investment in $R \& D$ and the screening and spread of new technology - - involve considerable uncertainty. Unionized firms engaged in innovative activities must deal with an additional source of uncertainty, namely the reaction of the union. In addition to the question of how much of the returns to any sort of innovative activity (product or process) will have to be shared with the union, there is also the issue of the willingness of unions to agree to changes in the production process. The expected returns to innovation may not only be lower 
under unionism, but they may also be more unpredictable. If so, this would result in an even slower rate of technical change under unionism.

Now consider the institutional effects of unions on productivity growth. In most cases unions do not attempt to prevent management from introducing new techniques, mainly because the consequences of doing so are almost always self-destructive. Two specific cases cited by Bok and Dunlop (1970) are the attempts of the window-glass workers to stop the glass making machine in 1908 and the efforts of the cigar makers to halt specialization and new machinery. The window-glass union had to be officially disbanded in 1928 while percentage unionized in the cigar industry dropped from 45 to 20 percent. Instead of obstructing new technology, Bok and Dunlop conclude (p.262) that "labor leaders have normally chosen to accept new methods and share in the gains which these innovations make possible." A key exception to this general rule, they note, seems to be the case of "older members with a short, remaining working life and with little interest in moving or learning new skills, [who] may even find rational grounds for sacrificing their union in order to prolong their jobs until retirement $(\mathrm{p} .262) . "$

Even if unions rarely attempt to block the introduction of new technology, they can still make the introduction of new technology more costly. In almost every case management must consult with the union before making any changes in work assignments, skill requirements, number of positions, or plant and equipment. Slichter, Healy and Livernash (1960) note that this will generally raise questions regarding craft jurisdiction, seniority, wage adjustments, and treatment of any displaced workers. Problems are most likely to arise when management must deal with a number of craft unions simultaneously. Even though management may at times receive highly valuable input from the union, on 
balance one would expect that the greater cost of introducing new technology under unionism should make the introduction of such technology less likely than in a nonunion setting.

However, there are also many cases in which the unions themselves have actively encouraged firms to make changes that workers believe will lead to more job security and higher wages. Slichter, Healy, and Livernash note that such a policy "usually is followed when the union is worried about the ability of an industry or a plant to hold its own in competition (p.355)." For instance they point out that the engineering departments of the needle trades have at times suggested technological changes to employers and assisted the employer in implementing them, performing a role similar to that of the extension service in agriculture. Unions also have generated technical improvements in plants with profit sharing or employee participation programs. Currently, the growing emphasis on work organization and efficiency in quality-of-work-life (QWL) programs is another example of unions acting to promote productivity growth. To the extent that workers feel that they are more likely to share in the benefits of QWL programs under unionism, those programs may turn out to be more successful in a union than a nonunion setting. Thus, the "voice" aspects of union behavior are far from irrelevant in the analysis of productivity change.

On balance the above discussion indicates that considering both price theoretic and institutional aspects of union behavior and managerial response, the impact of unions on productivity growth is an empirical question. I turn now to a survey of existing evidence, all of which comes from the manufacturing sector. 


\section{PREVIOUS EVIDENCE FROM MANUFACTURING}

Only two studies have focused on the effects of unionization on productivity growth. Hirsch and Link (1984) found slower productivity growth in industries where percentage unionized is high and in those where that percentage is rising. Freeman and Medoff (1984) found no correlation between unionization and productivity growth in three different samples. There is, however, additional evidence on this question in a number of other studies where, although the emphasis has been on estimating the impact of R\&D on productivity growth, percentage unionized has. been included as a control variable. The samples in some of these studies are almost identical to that used by Hirsch and Link and to one of the samples used by Freeman and Medoff. Thus examination of their findings not only provides a wider base of evidence, but also serves as an independent check on the robustness of the Hirsch and Link and the Freeman and Medoff results.

The results of all studies of productivity growth which include unionization as a right-hand variable are summarized in Table 1 . All of the studies are limited to manufacturing and are grouped in Table 1 according to whether they use data on industries (at various levels of aggregation) or firms. For each study the table describes the sample, reports the measures of productivity and unionization, lists the control variables, and summarizes the results for the union variable(s).

The studies summarized on the first four lines all use data sets consisting of two-digit industries over various intervals. The first three of these consistently find much slower average annual productivity growth in unionized industries, with the estimates of the union-nonunion difference ranging between 
4 and 6 percentage points. Even at the lower bound, this implies that over an 18 year period there will be twice as much productivity growth in a nonunion industry compared to a unionized industry, implying that unions anathematize economic progress.

There are good reasons to question these findings. The results obtained by Kendrick and Grossman for the change in unionization variable imply that a 10 percentage point increase in unionization results in 1.8 percent faster productivity growth. Although they attribute this finding to multicollinearity of the change in unionization with other variables, it could just as easily be explained in terms of "shock effects" in cases where unionization is growing and in terms of increased turnover and lower labor quality in cases where unionization is falling. Also, Terleckyj's (1980) findings indicate that the estimated effect of the initial level of unionization is very sensitive to which total factor productivity measure is used as the dependent variable. He finds a significant negative union impact on productivity growth for only two out of four measures.

The biggest problem with these results lies in the nature of the data. At the two-digit SIC level of aggregation it is impossible to determine whether unions directly reduce productivity growth or whether unions are most likely to be found in industries with limited opportunities for technical advancement. Percentage unionized is highest in "smokestack" industries such as primary metals, transportation equipment, and paper where the products and the production process changed very little over the sample periods examined in these studies. The only way to control for differences across industries in opportunities for productivity growth is to construct a data set with some predominantly union and some predominantly nonunion observations within each 
industrial category. This can be done by either using a finer level of aggregation than the very crude two-digit level or breaking down the two-digit industries by some other variable, such as location.

The remaining industry studies cited in Table 1 follow one of these two strategies. Terleckyj (1984) breaks a few two-digit industries down into their major three-digit components and finds significantly lower productivity growth under unionism in only one out of three specifications -- one where he includes R\&D embodied in purchased capital goods but excludes R\&D spending. When the latter R\&D variable is included (with or without the embodied R\&D measure), he finds no link between unionism and productivity growth. In a sample of 138 three-digit industries, Sveikauskas and Sveikauskas (1982) find no correlation between unionization and productivity growth in any of the seven equations they report. Freeman and Medoff examine one sample of three-digit industries, another sample of four-digit industries, and another consisting of two-digit industries broken down by state or region. As noted earlier, in all three cases they find slower productivity growth under unionism, but the relationship is not statistically significant.

The main conclusion that can be drawn from the industry studies surveyed here is that there is little reason to believe that unions have acted as a major obstacle to productivity growth in manufacturing. Although the sign of the union coefficient is almost always negative, in the most careful studies the estimated effect of unions is rather small and estimated with relatively little precision.

The results of three studies using data sets consisting of individual firms or lines of business within a firm are reported on the last three lines of Table 1. This type of data provides another way to obtain observations by 
union status within a particular industry, thus allowing independent variation in unionism and technological opportunities. This flexibility is obtained at the cost of limiting the sample to large, publicly traded firms and, in some cases, measuring unionization inaccurately. Two studies by Link find dramatically slower productivity growth in firms which seem to be predominantly unionized. Link's measure of unionization in both of these studies is percentage unionized in the three-digit industry in which the firm mainly operates. His samples are limited to a small number of industries, all of which have average to above average levels of unionization. Clark and Griliches find productivity grows at a one percent faster rate under unionism, but the union coefficient is the same size as its standard error. Thus, the studies using data on firms also fail to provide any conclusive evidence that unions have any direct effect on productivity growth.

One indirect mechanism not considered in any of the studies summarized in Table 1 may be quite important. Connolly, Hirsch, and Hirschey (1986) report evidence from a sample of 367 firms from the Fortune 500 that investment in R\&D adds less to the market value of firms in unionized industries and that firms in those industries respond to this by investing in less R\&D. This means that holding R\&D intensity constant in an oLS equation may not be the appropriate method for estimating the total impact of unionization on productivity growth. By failing to consider this indirect effect, the studies surveyed above may very well be underestimating the total impact of unionization. Further work with more broadly representative data sets is clearly needed to establish the robustness of Connolly, Hirsch and Hirschey's findings with respect to union effects on R\&D and how this influences estimates of the union impact on productivity growth. 
IV. NEW EVIDENCE FOR MANUFACTURING

Because of the absence of any firm conclusions on the links between unionism and productivity growth in the studies surveyed above, this issue was re-examined over a sample of 74 three and four digit industries for which U.S. Department of Labor (1986) reports indexes of output per employee hour between 1972 and 1983. Besides not being used in any previous study focusing on unionization and productivity growth, this data set merits examination because the output measures are based mainly on physical quantities, which should make them extremely accurate, and because it covers a more recent time period, one where union density has been declining rapidly.

The percentage growth in the labor productivity index in each industry is assumed to be a function of R\&D intensity, four-firm concentration ratio, and unionization. Scherer (1984) constructed two measures of 1974 R\&D activity: one indicating R\&D originating in each industry and a second indicating R\&D used by each industry. The second measure was obtained by using an input-output table to estimate how much of the R\&D originating in a particular industry was used in other sectors. Each measure of R\&D spending was converted into a measure of $R \& D$ intensity by dividing it by value added in 1974, as reported in the Annual Survey of Manufactures. Both the initial level and the change in the concentration and unionization variables were included as right-hand side variables. The concentration ratios come from the Censuses of Manufacturing for 1972 and 1982. The initial level of unionization is the value reported by Freeman and Medoff for production workers from the pooled May 1973-75 CPS tapes; the final level was estimated by the author from the May 
1983 CPS pension supplement public use tape. The results are reported in Table 2.

Productivity growth is strongly related to concentration and R\&D in this sample, but it is unrelated to unionization. Productivity tends to grow slightly faster in industries with high initial levels of unionization and markedly faster in industries where percentage union is declining most rapidly, but neither coefficient is statistically significant in any specification. In results not reported in Table 2 , the equations were re-estimated with union variables calculated across all occupations; the union coefficients were even smaller. This new evidence re-enforces the main conclusion from the previous studies surveyed in Section III - there is no direct connection between unionization and productivity growth in manufacturing.

One limitation of this analysis is that it holds R\&D intensity constant, whereas the models discussed in Section II imply that unions could reduce R\&D. Even when R\&D intensity is dropped from the model in column 6 of Table 2, there is no relationship between unionization and productivity growth. To test the linkage between $R \& D$ and unionization directly, each $R \& D$ intensity measure was regressed on unionization and the concentration ratio. The results, reported in Table 3, show that unionized industries spend much less money on $R \& D$. The ratio of $R \& D$ originating to output is 12 percentage points less in an industry where all production workers belong to unions than in an industry where none do. The ratio of R\&D used to output is 17 percentage points lower in unionized than nonunion industries. Increased concentration is associated with higher R\&D spending in this sample.

Both union coefficients are dramatically larger than the mean of the dependent variable and, if taken literally, imply the mean ratio of R\&D to 
output in unionized industries is negative. This suggests that the model is overly simple. There are many important variables which remain to be considered, along with different possible routes of causation. Nonetheless, the results are very consistent with those of Connolly, Hirsch, and Hirschey and point to the need for more careful analysis of the union-R\&D-productivity link in the future.

\section{EVIDENCE FROM THE CONSTRUCTION INDUSTRY}

Construction is widely thought of as an industry in which very little technological progress has been made and where there are very limited opportunities for future productivity growth. Government statistics systematically overstate the growth of prices in the industry because they assume prices grow at the same rate as a weighted average of wages and material costs, disregarding the relationship between wages and productivity. This understatement of productivity growth is partly responsible for the perception that there has been little progress, along with the popular wisdom that the jobs of painters, plumbers, electricians, and carpenters have not changed in at least 30 years. Interestingly, productivity growth in construction was above the nonmanufacturing average between 1948 and 1968. Allen (1985) shows that much of the alleged decline in construction productivity since then is attributable to biases in the data.

Tatum (1984) cites two major sources of innovation in construction. One is changes in the design of projects so that they can be built with less labor or materials. The other is changes in the construction process itself. This can include: "(1) development of new construction methods or sequences; (2) 
application or extension of methods or techniques originally developed to meet other requirements; (3) development and application of new equipment and tools; and (4) scale-up or refinement of existing methods." (Tatum, pp. 311-2) For instance, a case study of the highway construction industry by Koch and Moavenzadeh (1979) shows that the main source of productivity growth in that sector between the 1950 s and the 1970s was improvements in equipment. They attribute this to competition among equipment manufacturers, changes in highway design including some standardization of certain features, relatively stable demand (because of the use of user fees to fund highway construction and repair), and the increased price of labor relative to capital. Rosefielde and Mills (1979) cite other sources of productivity growth in the construction industry, including the widespread adoption of power tools and machinery, introduction of larger lifting and moving machinery, changes in the use of building materials which economize on labor time (such as drywall for plaster, movable partitions for walls), and increased use of prefabricated components.

Where do these innovations come from? It is quite clear that they do not come from $R \& D$ done by firms in the construction industry itself. Scherer estimates that these firms do only $\$ 28$ million a year, a small amount compared to the size of the industry. A study recently completed for the Building Research Board of the National Research Council (1986) also found very little government spending on R\&D related to construction. One potentially important factor is R\&D embodied in capital goods and materials purchased by the construction industry. Scherer estimates that R\&D spending by companies in al1 industries which is used by companies in construction amounts to $\$ 432.9$ million. 
The predominance of craft as opposed to industrial unionism in construction makes this industry an especially interesting case to consider for examining how unions affect productivity growth. Unions are most likely to influence productivity growth in construction through relative factor prices and work rules. The small amount of $R \& D$ done by firms in the construction industry makes it unlikely that this route of union influence is very important.

Pooled data from the 1972, 1977, and 1982 Censuses of Construction Industries are used here to estimate the effect of unions on productivity growth in construction. There are separate observations in each year for three two-digit industries and 27 states or regions identified in the May 1973-75 Current Population Survey (CPS). The 1972 data set is the same as that in Allen (1984) and the 1977 and 1982 data sets are constructed in exactly the same way. The May 1977-78 CPS is used to estimate percentage unionized and 1abor quality for 1977; the May 1979-81 CPS, for 1982.

The productivity variable used in Table 4 is the change in the log of total factor productivity. Total factor productivity is the ratio of output to a weighted average of capital and labor inputs. The weights in each year equal the input shares in that year. To convert monetary to real values, variables were deflated to 1972 dollars. The output measure used below is value added. It was deflated by the deflator for construction industry GNP in the national income accounts and by the Dodge Cost Index (where New York City $=100$ ). These adjustments control for differences across states or regions in price levels in 1972 and the rates of price increase since 1972. The capital variable equals the sum of (1) the service flow from owned capital and (2) expenditures on rented machinery and structures. It was deflated with an index of durable equipment prices, weighted by the share of each type of equipment in 
construction, as reported by Boddy and Gort (1971). The weights for education, age, occupation and region in the labor quality index are all based on wage equation coefficients for nonunion workers (with separate coefficients for men and women) from the 1977-78 CPS. This removed year-to-year variation in wage equation coefficients as a source of labor quality variation.

Estimates of equations (1) and (3) are reported in Table 4, along with an extension of (3) where productivity growth is also allowed to be a function of the initial levels of average establishment size and labor quality (denoted $\left(3^{\prime}\right)$ in the table). The model was also estimated (1) under the assumption of constant factor shares and (2) with labor productivity as the dependent variable. These results were the same as those in Table 4 and are not reported. The estimates of (1) show that productivity growth is slower in state by industry cells where unionization is growing, but the coefficient is smaller than its standard error.

Two stronger conclusions emerge from the estimates of (3). First, productivity growth is much slower in areas with high levels of unionization. The union-nonunion difference in productivity growth, in terms of annual rates of change and assuming no productivity growth under unionism, is between 3.8 and 5.3 percent. Second, productivity growth is also much slower in areas where the proportion of union workers is rising. The change in unionization coefficient falls from. -.173 in the estimate of (1) to -.456 in (3). The level of unionization and the change in unionization coefficients are both economically and statistically significant, implying that the specification in (3) is to be preferred to that in (1). To test whether the initial level of unionization is acting as a proxy for initial levels of other variables which might contribute to productivity growth, (3) was extended to include the 
initial values of the labor quality index and average establishment size. Inclusion of these two variables caused the coefficient of the initial level of unionization to drop even further from -.375 to -.516 .

Do the results in Table 4 reflect a one-time shock to $c$ as described in (2) or do they indicate different trends in productivity growth as described in (3)? One way to distinguish these two interpretations is to estimate the model over shorter periods and see if the results are the same in each period. If they are, this would indicate that the results should be interpreted in terms of a trend rather than a single shock. The market share of union contractors was falling between 1972 and 1982, but Allen (1986) shows that the rate of decline was steepest after 1977. Also, 1982 was the last year of an extended period of depressed output in construction. To test the robustness of the results in terms of stability over different periods, separate models were estimated for 1972-1977 and 1977-1982. The results, in the last six columns of Table 4, show only one important difference between the two periods. Whereas the initial level of unionization is inversely related to productivity growth in both periods, the relationship between changes in unionization and productivity growth holds up for 1977-1982 but not for 1972-1977. This probably results from either the relatively modest drop in unionization in the earlier period or greater variation in the change in unionization in the later period.

If the means of the dependent variables are taken seriously, these results imply that productivity was falling in both the union and nonunion sectors over this period. Most of this alleged productivity decline results from overestimation of the rate of price increase in construction and the absence of any controls for changes in the mix of construction, as discussed in Allen 
(1985). Once adjustments are made for these factors, the change in productivity over this period is negligible. If the rate of productivity growth for the industry is assumed to be zero, the estimates of the union-nonunion difference in productivity growth in Table 4 still imply that productivity was falling in union construction while rising in nonunion construction.

There are no obvious sources of declining productivity in union construction over this period. Strike activity has fallen since 1975, indicating no deterioration in labor-management relations akin to that in the coal industry. There was no change in this period in the share of workers covered by agreements limiting or prohibiting subcontracting, limiting or regulating crew size, and restricting work by those outside the bargaining unit. Thus, the possibility that productivity in union construction stayed constant, rather than declining, should not be ruled out. The results in Table 4 would then imply very rapid productivity growth in nonunion construction.

Regardless of whether productivity in union construction was constant or falling during this period, there is still the question of why the productivity gap between union and nonunion construction narrowed. Most construction-related $R \& D$ is done in industries which supply materials and equipment to construction firms. The growth in capital input or the change in the capital-1abor ratio is the best available signal of this form of innovative activity in the CCI data. Although included as a control variable in Table 4, one could reasonably argue that to estimate the true impact of unionism, capital must be viewed as an endogenous variable in a system of equations.

To test this, both the change in capital input and the change in the capital-labor ratio were regressed on the exogenous variables in equation ( $3^{\prime}$ ) 
over the same sample used in Table 4. The strongest correlate of the change in capital and the change in the capital-labor ratio across region-industry cells was the change in labor quality, which had a negative coefficient. The change in unionization and the initial level of unionization coefficients were smaller than their standard errors in both equations. Thus, the change in capital in the CCI data not seem to be directly linked with the unionization patterns in the CPS data.

A question which cannot be addressed with these data is how to interpret the results in light of the growing share of union workers who seem to be working for nonunion contractors and the growing share of union contractors which have opened nonunion subsidiaries. For instance, the data on capital input indicate that union contractors have invested just as much as nonunion contractors. This finding can be misleading if the union contractors put most of their new capital into their nonunion "double-breasted" subsidiaries.

A number of labor-market related causes of the decline in the union-nonunion productivity difference are discussed in some detail in Allen (1986). The rising share of union members working in the open shop seems to have eroded the training advantage which union contractors once possessed over their nonunion competition. It is also likely that the high unemployment rates observed during much of this period significantly eroded the search economies offered by union hiring halls.

\section{CONCLUSION}

This paper has examined the ways in which unions can affect productivity growth and presented evidence from manufacturing and construction. While cross section studies which estimate union-nonunion differences in productivity 
levels frequently find productivity to be higher under unionism, the results reported here show that unionism has little effect on productivity growth in construction. The main reason for the difference in the results between manufacturing and construction probably lies in the dominance of the craft form of unionization in construction. As noted by Slichter, Healy, and Livernash, the introduction of changes in the work place is much more costly under this form of unionism and this makes innovation less likely to occur.

There is evidence that the building trades unions are aware of this problem and have begun to do something about it. In a number of areas contractors and unions have formed cooperative associations to generate productivity improvements. In St. Louis PRIDE (Productivity and Responsibility Increase Development and Employment) was launched in 1972. This group, which also includes owners, engineers, architects, and equipment and materials suppliers, has been so successful that employment of union craftsmen has actually increased by 35 percent and the open shop has made little headway in that area. In 1982 the AFL-CIO Building Trades Department and the National Construction Employers Council launched a "Market Recovery Program for Union Construction" which aims to emulate this approach nationwide. The results of these efforts will determine whether the effect of unions on productivity change can vary over time in a particular industry, an issue beyond the scope of this paper but which should be examined in future work. 
Table 1. Studies of Unionization and Productivity Change in Manufacturing.

\begin{tabular}{|c|c|c|c|c|c|}
\hline & & $\begin{array}{l}\text { Measure of } \\
\text { Productivity }\end{array}$ & Meastrre of & & \\
\hline Study & Sample & $\begin{array}{l}\text { Change and } \\
\text { Source }\end{array}$ & $\begin{array}{l}\text { Unionization } \\
\text { and source }\end{array}$ & $\begin{array}{l}\text { Control } \\
\text { Variables }\end{array}$ & $\begin{array}{l}\text { Impact of Unionization on } \\
\text { Armual Productivity Growth }\end{array}$ \\
\hline
\end{tabular}

Studies using industry data

1. Kendrick and Grossman (1980)

3. Hirsch and Link (1984)

4. Terleckyj (1980)

5. Terleckyj (1984)

6. Sveikauskas and Sveikauskas (1982)

138 3-digit, Own 1959-1969
a. 176 3-digit own 1958-76
b. 450 4-digit $G(1984)$ 1958-78
c. 341 2-digit Own by state or region, 1972-77 Medoff (1984) 1948-66

19 2-digit, 1957-73

20 2-digit, 1948-66

272 and

3-digit, 1969-76

$\begin{array}{llll}20 \text { 2-digit, Own } & \text { Level: K (1973) } & \text { R\&D, CR, } \\ \text { 1948-76 } & & \text { Change: ow } & \text { FEM, CAPUIIL }\end{array}$

20 2-digit, K (1973) Level: K (1973) R\&D CAT

GJ (1980)

Leve1: FM (1979) R\&D, CR, PVT, Change: FM (1979) CYC
a. K (1973)
Ievel: own
b. GJ
c. Revised GJ
d. KG (1980)

GL (1984)

Leve1: FM (1979)

a. RED

b. EMB R\&D

c. RED, EMB REDD

Leve1: FM (1979) DY, SIZE, R\&D, insignificant .44 percent GR slower to .01 percent faster under unionism
Leve1: FM (1979) None
Leve1: FM (1979)

3.6 percent slower under unionism; 1.8 percent faster where union share rises by 1 percentage points

\section{4 to 6.1 percent slower} under unionism

3.6 to 4.4 percent slower under unionism and 0.5 to 0 . percent slower where union share rises by 10 percentage points
a. 4 percent slower under unionism
b. Insignificant 3 percent slower under unionism
c. 3 percent slower under unionism
d. Insignificant 2 percent slower under umionism
a. Insignificant 0.5 percent slower under unionism
b. 1.0 percent slower under unionism
c. Insignificant 0.5 percent slower under unionism
a. Insignificant .4 percent slower under unionism
b. insignificant .3 percent slower under unionism
c. insignificant .3 percent slower under unionism


Table 1 (Contimued)

\begin{tabular}{|c|c|c|c|c|c|}
\hline Study & Sample & $\begin{array}{l}\text { Measure of } \\
\text { Productivity } \\
\text { Change and } \\
\text { Source }\end{array}$ & $\begin{array}{l}\text { Measure of } \\
\text { Unionization } \\
\text { and Source }\end{array}$ & $\begin{array}{l}\text { Control } \\
\text { Variables }\end{array}$ & $\begin{array}{l}\text { Impact of Unionization on } \\
\text { Anmual Productivity Growth }\end{array}$ \\
\hline
\end{tabular}

Studies using industry data
8. Link (1981)
51 firms in
7 industries,
$1973-78$
own
Leve1: FM (1979) R\&D CAT
2.5 percent slower under unionism
9. Link (1982) 97 firms in
3 industries,
$1975-79$
own
Level: FM (1979) a. RSD
b. R\&D CAT
a. 10.3 percent slower under unionism
b. 9.2 percent slower under unionism
10. Clark and
Griliches (1984)
924 "businesses" Own
in PTMS data,
Level: own
R\&D, R\&D CAT, insignificant 1 percent 1970-1980
insignificant 1 percent
higher under unionism

Notes: Dependent variable is growth in total factor productivity growth except for Freeman and Medoff, which uses growth to labor productivity. All results for impact of unionization are statistically significant at conventionally accepted confidence levels unless otherwise noted.

Key to sources of productivity and unionization measures:

FM = Freemen and Medoff

$\mathbf{G J}=$ Collop and Jorgensen

$\mathrm{K}=$ Kendrick

$G=$ Gray

GL = Griliches and Ifchtenberg

$\mathrm{KG}=$ Kentrick and Grossman

Key to control varlables:

CAPUIIL = Capacity utilization ratio

$C R=$ Concentration ratio

CYC $=$ Index of cyclical instability of industry output

$D Y=$ Output growth
EMB RSD = R\&D embodied in capital goods purchased from other industries
REC $=$ Newness of capital stock
SIZE = Shares of workers in firms with 500 or less and 2500 or more workers
R\&D CAT = R\&D intensity coefficient allowed to vary for different categories for RED

$R \& D=$ Ratio of total R\&D to output 
Table 2. Labor Productivity Growth Equations, 743 and 4-Digit Manufacturing Industries 1972-83.

\begin{tabular}{|c|c|c|c|c|c|c|c|}
\hline & $\begin{array}{c}\text { Mean } \\
\text { (S.D.) } \\
\end{array}$ & (1) & (2) & (3) & (4) & (5) & (6) \\
\hline Constant & & $\begin{array}{l}1.045 \\
(.059)\end{array}$ & $\begin{array}{l}.956 \\
(.124)\end{array}$ & $\begin{array}{l}.936 \\
(.098)\end{array}$ & $\begin{array}{l}.868 \\
(.141)\end{array}$ & $\begin{array}{l}.937 \\
(.135)\end{array}$ & $\begin{array}{l}1.016 \\
(.125)\end{array}$ \\
\hline $\begin{array}{l}\text { Unionization } \\
\text { 1973-75 }\end{array}$ & $\begin{array}{l}.505 \\
(.139)\end{array}$ & & $\begin{array}{l}.186 \\
(.229)\end{array}$ & & $\begin{array}{l}.155 \\
(.229)\end{array}$ & $\begin{array}{l}.096 \\
(.230)\end{array}$ & $\begin{array}{l}-.009 \\
(.221)\end{array}$ \\
\hline $\begin{array}{l}\text { Change in } \\
\text { unionization, } \\
1973-75 \text { to } 1983\end{array}$ & $\begin{array}{l}-.116 \\
(.060)\end{array}$ & & & $\begin{array}{l}-.705 \\
(.510)\end{array}$ & $\begin{array}{l}-.668 \\
(.515)\end{array}$ & $\begin{array}{l}-.457 \\
(.508)\end{array}$ & $\begin{array}{l}-.381 \\
(.509)\end{array}$ \\
\hline $\begin{array}{l}\text { Concentration } \\
\text { ratio in } 1972\end{array}$ & $\begin{array}{l}.388 \\
(.217)\end{array}$ & $\begin{array}{l}.386 \\
(.131)\end{array}$ & $\begin{array}{l}.360 \\
(.135)\end{array}$ & $\begin{array}{l}.437 \\
(.135)\end{array}$ & $\begin{array}{l}.412 \\
(.141)\end{array}$ & $\begin{array}{l}.373 \\
(.146)\end{array}$ & $\begin{array}{l}.416 \\
(.144)\end{array}$ \\
\hline $\begin{array}{l}\text { Change in } \\
\text { concentration, } \\
1972-82\end{array}$ & $\begin{array}{l}-.003 \\
(.060)\end{array}$ & $\begin{array}{l}1.194 \\
(.484)\end{array}$ & $\begin{array}{l}1.236 \\
(.488)\end{array}$ & $\begin{array}{l}1.170 \\
(.481)\end{array}$ & $\begin{array}{l}1.206 \\
(.486)\end{array}$ & $\begin{array}{l}1.273 \\
(.492)\end{array}$ & $\begin{array}{l}1.340 \\
(.494)\end{array}$ \\
\hline $\begin{array}{l}\text { R\&D intensity } \\
\text { by use }\end{array}$ & $\begin{array}{l}.028 \\
(.056)\end{array}$ & $\begin{array}{l}.831 \\
(.508)\end{array}$ & $\begin{array}{l}1.003 \\
(.551)\end{array}$ & $\begin{array}{l}1.067 \\
(.533)\end{array}$ & $\begin{array}{l}1.197 \\
(.568)\end{array}$ & & \\
\hline $\begin{array}{l}\text { R\&D intensity } \\
\text { by origin }\end{array}$ & $\begin{array}{l}.036 \\
(.048)\end{array}$ & & & & & $\begin{array}{l}.954 \\
(.652)\end{array}$ & \\
\hline$\sigma$ & & .240 & .240 & .238 & .239 & .243 & .245 \\
\hline $\mathrm{R}^{2}$ & & .195 & .203 & .217 & .222 & .196 & .171 \\
\hline
\end{tabular}

The mean (S.D.) of the dependent variable is $1.214(.262)$. 
Table 3. R\&D Intensity Equations, 743 and 4-Digit Manufacturing Industries, 1974.

\begin{tabular}{|c|c|c|}
\hline & $\begin{array}{l}\text { Dependent } \\
\text { Ratio of R\&D Originating } \\
\text { To Output }\end{array}$ & $\begin{array}{l}\text { Variable } \\
\text { Ratio of R\&D Used } \\
\text { To Output }\end{array}$ \\
\hline Constant & $\begin{array}{l}.079 \\
(.020)\end{array}$ & $\begin{array}{l}.104 \\
(.024)\end{array}$ \\
\hline $\begin{array}{l}\text { Unionization } \\
\text { 1973-75 }\end{array}$ & $\begin{array}{l}-.122 \\
(.039)\end{array}$ & $\begin{array}{l}-.167 \\
(.045)\end{array}$ \\
\hline $\begin{array}{l}\text { Concentration } \\
\text { ratio in } 1972\end{array}$ & $\begin{array}{l}.050 \\
(.025)\end{array}$ & $\begin{array}{l}.020 \\
(.030)\end{array}$ \\
\hline$\sigma$ & .045 & .052 \\
\hline $\mathrm{R}^{2}$ & .141 & .161 \\
\hline $\begin{array}{l}\text { Mean (S.D.) of } \\
\text { dependent } \\
\text { variable }\end{array}$ & $\begin{array}{l}.036 \\
(.048)\end{array}$ & $\begin{array}{l}.028 \\
(.056)\end{array}$ \\
\hline
\end{tabular}


Table 4. Change in Total Factor Productivity Equations.

Sample Period and Equation

$1972-1982$

$1972-1977$

1977-1982

(1)

(3)

(3')

(1)

(3)

(3')

(1)

(3)

(3')

\begin{tabular}{|c|c|c|c|c|c|c|c|c|c|}
\hline Intercept & $\begin{array}{l}-.289 \\
(.028)\end{array}$ & $\begin{array}{l}-.160 \\
(.055)\end{array}$ & $\begin{array}{r}-1.187 \\
(.611)\end{array}$ & $\begin{array}{l}-.142 \\
(.021)\end{array}$ & $\begin{array}{l}-.098 \\
(.044)\end{array}$ & $\begin{array}{r}-1.210 \\
(.487)\end{array}$ & $\begin{array}{l}-.160 \\
(.025)\end{array}$ & $\begin{array}{l}-.060 \\
(.060)\end{array}$ & $\begin{array}{l}-.352 \\
(.596)\end{array}$ \\
\hline $\begin{array}{l}\text { Change in } \\
\text { union }\end{array}$ & $\begin{array}{l}-.173 \\
(.200)\end{array}$ & $\begin{array}{l}-.456 \\
(.220)\end{array}$ & $\begin{array}{l}-.451 \\
(.217)\end{array}$ & $\begin{array}{l}.082 \\
(.144)\end{array}$ & $\begin{array}{c}.003 \\
(.159)\end{array}$ & $\begin{array}{c}.005 \\
(.156)\end{array}$ & $\begin{array}{l}-.160 \\
(.168)\end{array}$ & $\begin{array}{l}-.303 \\
(.182)\end{array}$ & $\begin{array}{l}-.320 \\
(.194)\end{array}$ \\
\hline $\begin{array}{l}\text { Change in } \\
\text { labor quality }\end{array}$ & $\begin{array}{l}-.475 \\
(.489)\end{array}$ & $\begin{array}{l}-.739 \\
(.480)\end{array}$ & $\begin{array}{l}-.515 \\
(.527)\end{array}$ & $\begin{array}{l}-.503 \\
(.352)\end{array}$ & $\begin{array}{l}-.484 \\
(.352)\end{array}$ & $\begin{array}{l}-.128 \\
(.378)\end{array}$ & $\begin{array}{l}.206 \\
(.380)\end{array}$ & $\begin{array}{l}-.007 \\
(.391)\end{array}$ & $\begin{array}{l}.097 \\
(.440)\end{array}$ \\
\hline $\begin{array}{l}\text { Change in } \\
\text { establishment } \\
\text { size }\end{array}$ & $\begin{array}{c}.844 \\
(.127)\end{array}$ & $\begin{array}{c}.808 \\
(.123)\end{array}$ & $\begin{array}{c}.845 \\
(.122)\end{array}$ & $\begin{array}{c}.794 \\
(.122)\end{array}$ & $\begin{array}{l}.799 \\
(.121)\end{array}$ & $\begin{array}{c}.809 \\
(.117)\end{array}$ & $\begin{array}{l}.795 \\
(.133)\end{array}$ & $\begin{array}{l}.722 \\
(.137)\end{array}$ & $\begin{array}{c}.717 \\
(.142)\end{array}$ \\
\hline $\begin{array}{l}\text { Initial level } \\
\text { of union }\end{array}$ & & $\begin{array}{l}-.375 \\
(.140)\end{array}$ & $\begin{array}{l}-.516 \\
(.158)\end{array}$ & & $\begin{array}{l}-.126 \\
(.110)\end{array}$ & $\begin{array}{l}-.304 \\
(.134)\end{array}$ & & $\begin{array}{l}-.277 \\
(.150)\end{array}$ & $\begin{array}{l}-.321 \\
(.175)\end{array}$ \\
\hline $\begin{array}{l}\text { Initial level } \\
\text { of labor qualit }\end{array}$ & & & $\begin{array}{c}.584 \\
(.386)\end{array}$ & & & $\begin{array}{l}.636 \\
(.313)\end{array}$ & & & $\begin{array}{l}.196 \\
(.379)\end{array}$ \\
\hline $\begin{array}{l}\text { Initial level } \\
\text { of establishmen } \\
\text { size }\end{array}$ & & & $\begin{array}{c}.057 \\
(.034)\end{array}$ & & & $\begin{array}{c}.067 \\
(.028)\end{array}$ & & & $\begin{array}{l}-.004 \\
(.034)\end{array}$ \\
\hline$\sigma$ & .198 & .190 & .187 & .159 & .159 & .152 & .186 & .184 & .186 \\
\hline $\mathrm{R}^{2}$ & .371 & .426 & .459 & .370 & .381 & .445 & .329 & .358 & .361 \\
\hline $\begin{array}{l}\text { Mean (S.D.) } \\
\text { of dependent } \\
\text { variable }\end{array}$ & $\begin{array}{l}-.304 \\
(.245)\end{array}$ & $\begin{array}{l}-.304 \\
(.245)\end{array}$ & $\begin{array}{l}-.304 \\
(.245)\end{array}$ & $\begin{array}{l}-.196 \\
(.196)\end{array}$ & $\begin{array}{l}-.196 \\
(.196)\end{array}$ & $\begin{array}{l}-.196 \\
(.196)\end{array}$ & $\begin{array}{l}-.108 \\
(.223)\end{array}$ & $\begin{array}{l}-.108 \\
(.223)\end{array}$ & $\begin{array}{l}-.108 \\
(.223)\end{array}$ \\
\hline
\end{tabular}


REFERENCES

Allen, Steven. "Unionized Construction Workers Are More Productive." Quarterly Journal of Economics 99 (1984): 251-274.

. "Why Construction Industry Productivity Is Declining." Review of Economics and Statistics 67 (1985): 661-669.

. "Declining Unionization in Construction: The Facts and The Reasons." North Carolina State University Department of Economics and Business Faculty Working Paper No. 79, 1986.

Baldwin, Carliss. "Productivity and Labor Unions: An Application of the Theory of Self-Enforcing Contracts." Journal of Business 56

(1983): 155-185.

Boddy, Raford, and Gort, Michael. "The Substitution of Capital for Capital." Review of Economics and Statistics 53 (1971): 179-188.

Bok, Derek, and Dunlop, John. Labor and The American Community. New York: Simon and Schuster, 1970.

Clark, Kim, and Griliches, Zvi. "Productivity Growth and R\&D at the Business Level: Results from the PIMS Data Base." In R\&D. Patents, and Productivity, edited by Zvi Griliches. Chicago: University of Chicago Press, 1984.

Connerton, Marguerite; Freeman, Richard; and Medoff, James. "Industrial Relations and Productivity: A Study of the U.S. Bituminous Coal Industry." Mimeographed. Cambridge, Mass.: Harvard University, 1983.

Connolly, Robert; Hirsch, Barry; and Hirschey, Mark. "Union Rent Seeking, Intangible Capital, and Market Value of the Firm." Review of Economics and Statistics 68 (1986): 567-577. Freeman, Richard and Medoff, James. What Do Unions Do? New York: Basic,
1984.

Gollop, Frank and Jorgenson, Dale. "U.S. Productivity Growth by Industry, 1947-73." In New Developments in Productivity Measurement and Analysis, edited by John Kendrick and Beatrice Vaccara. National Bureau of Economic Research Studies in Income and Wealth, Vol. 44. Chicago: University of Chicago Press, 1980.

Gray, Wayne. "The Impact of OSHA and EPA Regulation on Productivity." National Bureau of Economic Research Working Paper No. 1405, 1984.

Griliches, Zvi and Litchtenberg, Frank. "R\&D and Productivity Growth at the Industry Leve1: Is There Still a Relationship?" In R\&D, Patents, and Productivity, edited by Zvi Griliches. Chicago: University of Chicago Press, 1984. 
Hirsch, Barry and Link, Albert. "Unions, Productivity, and Productivity Growth." Journal of Labor Research 5 (1984): 29-37.

Kendrick, John. Postwar Productivity Trends in the United States, 1948-1969. New York: Columbia University Press, 1973.

, and Grossman, Elliot. Productivity in the United States.

Baltimore: Johns Hopkins University Press, 1980.

Koch, Janet and Moavenzadeh, Fred. "Productivity and Technology in Construction." Journal of the Construction Division. ASCE 105 (1979): 351-366.

Link, Albert. "Basic Research and Productivity Increase in Manufacturing: Additional Evidence." American Economic Review 71 (1981): 1111-1112.

. "Productivity Growth, Environmental Regulations, and the Composition of R\&D." Bel1 Journal of Economics 13 (1982): 548-54.

Mansfield, Edwin. "Basic Research and Productivity Increase in Manufacturing." American Economic Review 70 (1980): 863-873.

National Research Council. Building Research Board Committee on Construction Productivity. Construction Productivity: Proposed Actions by the Federal Government to Promote Increased Efficiency in Construction. Washington: National Academy Press, 1986.

Ne1son, Richard. "Research on Productivity Growth and Differences." Journal of Economic Literature 19 (1981): 1029-1064.

Rosefielde, Steven, and Mills, D. Quinn. "Is Construction Technologically Stagnant?" In The Construction Industry, edited by Julian Lange and D. Quinn Mills. Lexington, Mass.: Heath, 1979.

Scherer, Frederic. "Using Linked Patent and R\&D Data to Measure Interindustry Technology Flows." In R\&D. Patents, and Productivity, edited by Zvi Griliches. Chicago: University of Chicago Press, 1984.

Slichter, Summer; Healy, James; and Livernash, Robert. The Impact of Collective Bargaining on Management. Washington: Brookings, 1960.

Sveikauskas, Catherine, and Sveikauskas, Leo. "Industry Characteristics and Productivity Growth." Southern Economic Journal 48 (1982): 769-774.

Tatum, Clyde. "What Prompts Construction Innovation?" Journal of Construction Engineering and Management 110 (1984): 311-323.

Tauman, Yair, and Weiss, Yoram. "Labor Unions and The Adoption of New Technology." Mimeographed. Tel-Aviv University, 1984.

Terleckyj, Nestor. "What Do R\&D Numbers Tell Us About Technological Change?" American Economic Review 70 (1980): 55-61. 
"Comment." In R\&D, Patents, and Productivity, edited by Zvi Griliches. Chicago: University of Chicago Press, 1984.

U.S. Department of Labor. Bureau of Labor Statistics. Productivity Measures for Selected Industries, 1958-84. BLS Bulletin 2256. Washington: G.P.O., 1986. 